\title{
ABIETANE DITERPENOIDS FROM PLECTRANTHUS GRANDIDENTATUS
}

\author{
António P. Teixeira, Olga Batista, M. Fátima Simões,* J. Nascimento, Aida Duarte, María C. de la Torre† \\ and BENJAMín RODRÍGUEZ†
}

Faculdade de Farmácia da Universidade de Lisboa, CECF, Av. das Forças Armadas, 1600 Lisboa, Portugal; †Instituto de Química Orgánica, CSIC, Juan de la Cierva 3, 28006 Madrid, Spain

(Received 31 May 1996)

Key Word Index-Plectranthus grandidentatus; Labiatae; diterpenes; abietanes; antibacterial activity.

\begin{abstract}
The acetone extract of the whole plant of Plectranthus grandidentatus provided the already known abietanes royleanone, 6,7-dehydroroyleanone, horminone, $6 \beta$-hydroxyroyleanone, $7 \alpha$-acetoxy- $6 \beta$-hydroxyroyleanone and the abietane dimers grandidone $C$, grandidone $\mathrm{D}$ and 7 -epigrandidone $\mathrm{D}$, together with a mixture of fatty acid esters of $7 \alpha$-acyloxy-6 $\beta, 12$-dihydroxy-abieta-8,12-diene-11,14-dione. Some of these compounds showed moderate antibacterial activity. Copyright (C) 1996 Elsevier Science Ltd
\end{abstract}

\section{INTRODUCTION}

In continuation of our studies on biologically active diterpenoids from Plectranthus plants [1-3], we have now investigated $P$. grandidentatus (whole plant). From the leaf-glands of this species have been isolated [4] the abietanes 14-hydroxytaxodione and coleons $\mathrm{U}$ and $\mathrm{V}$, and the abietane dimers grandidones A-D and 7-epigrandidones A, B and D. We report here on the isolation and identification of the abietane derivatives found in the whole plant acetone extract, as well as the results of the assays of some of these abietanes as antimicrobial compounds.

\section{RESULTS AND DISCUSSION}

Repeated chromatography of the acetone extract of $P$. grandidentatus (whole plant, see Experimental) allowed the isolation of the abietane dimers grandidones $\mathrm{C}$ and $D$ and 7-epigrandidone $D$, previously found in the leaf-glands of this species [4], together with the already known diterpenes royleanone (12-hydroxy-abieta-8,12diene-11,14-dione) $[5,6], 6,7$-dehydroroyleanone (12hydroxy-abieta-6,8,12-triene-11,14-dione) $[5,6]$, horminone (7 $\alpha, 12$-dihydroxy-abieta-8,12-diene-11,14dione) $[5,7], 6 \beta$-hydroxyroyleanone $(6 \beta, 12$-dihydroxyabieta-8,12-diene-11,14-dione) $[6,8], 7 \alpha$-acetoxy- $6 \beta$ hydroxyroyleanone $(1,7 \alpha$-acetoxy-6 $\beta, 12$-dihydroxyabieta-8,12-diene-11,14-dione) $[6,8-10]$, all of them found in Plectranthus and Coleus species. In addition, we have also isolated another compound (2), whose structure was established.

The ${ }^{1} \mathrm{H}$ NMR spectrum of 2 was almost identical

*Author to whom correspondence should be addressed. with that of 1 (Table 1), and the observed differences were consistent with the existence in the latter of a mixture of fatty acid esters at the $\mathrm{C}-7 \boldsymbol{\alpha}$ position $\left[\delta_{\mathrm{H}-7 \boldsymbol{\beta}}\right.$ $5.66 d, J=1.8 \mathrm{~Hz}, \delta_{\omega-\mathrm{Me}} 0.86,3 \mathrm{H}, t, J=6.9 \mathrm{~Hz}$, $\delta 5.33 \mathrm{~m}, 0.3 \mathrm{H}$ (olefinic protons), $\delta 2.25 \mathrm{~m}, 2.2 \mathrm{H}$ allylic and $\alpha$-methylenes) and $\delta 1.23 \mathrm{br} s, 26 \mathrm{H}$ (methylenes)] instead of the C-7 $\alpha$ acetoxyl group of the former $\left(\delta_{\mathrm{H}-7 \beta} 5.65 d, J=2.1 \mathrm{~Hz}, \delta 2.04 s, 3 \mathrm{H}, \mathrm{OAc}\right)$. Comparison of the UV spectra of $1\left(\lambda_{\max }^{\mathrm{MeOH}} \mathrm{nm}: 271\right.$ and 410) [6] and 2 ( $\lambda_{\max }^{\mathrm{MeOH}} n \mathrm{~nm}: 273$ and 409) further confirmed this deduction.

Hydrolysis of 2 , followed by methylation and GCMS analysis of the crude of the reaction, allowed the identification of the fatty acid methyl esters and established that 2 was a mixture of $7 \alpha$-palmityloxy $(71.7 \%)$, -stearyloxy $(12.8 \%)$, -oleyloxy $(6.1 \%),-n$-heptadecanoyloxy (3.9\%), -n-pentadecanoyloxy (2.9\%), -myristyloxy $(2.9 \%), \quad-6 \beta, 12$-dihydroxy-abieta-8,12diene-11,14-dione.<smiles>[R]C1C2=C(C(=O)C(C(C)P)=C(O)C2=O)[C@@]2(C)CCCC(I)(I)[C@@H]2[C@@H]1O</smiles>

$1 \mathrm{R}=\mathrm{OAc}$

$2 \mathbf{R}=$ Fatty acid esters 
Table 1. ${ }^{1} \mathrm{H}$ NMR spectral data of compounds $1^{*}$ and $2\left[300 \mathrm{MHz}, \mathrm{CDCl}_{3}, \delta\right.$ values relative to residual $\mathrm{CHCl}_{3}(\delta=7.25), J$ values in $\mathrm{Hz}]$

\begin{tabular}{|c|c|c|c|c|c|}
\hline $\mathrm{H}$ & $\mathbf{1}$ & 2 & $\mathrm{H}$ & $\mathbf{1}$ & 2 \\
\hline $1 \beta$ & $2.63 d t$ & $2.63 d t$ & $\mathrm{OH}(\mathrm{C}-12)$ & $7.18 \mathrm{~s}$ & $7.18 \mathrm{~s}$ \\
\hline $6 \alpha$ & $4.31 t$ & $4.30 t$ & OAc & $2.04 s$ & - \\
\hline $7 \beta$ & $5.65 d$ & $5.66 d$ & Fatty esters $\omega$-Me & - & $0.86 t(3 \mathrm{H})$ \\
\hline 15 & $3.16 \mathrm{sept}$ & 3.15 sept & Methylenes & - & $1.23 b r s(26 \mathrm{H})$ \\
\hline $\mathrm{Me}-16^{\mathrm{a}}$ & $1.22 d$ & $1.22 d$ & Allylic and $\alpha$ methylenes & - & $2.25 m(2.2 H)$ \\
\hline $\mathrm{Me}-17^{\mathrm{a}}$ & $1.19 d$ & $1.18 d$ & Olefinic protons & - & $5.33 m(0.3 \mathrm{H})$ \\
\hline Me-18 & $0.93 \mathrm{~s}$ & $0.93 s$ & & & \\
\hline Me-19 & $1.21 \mathrm{~s}$ & $1.22 \mathrm{~s}$ & & & \\
\hline $\mathrm{Me}-20$ & $1.60 s$ & $1.60 s$ & & & \\
\hline
\end{tabular}

J 1: $1 \alpha, 1 \beta=12.6,1 \beta, 2 \alpha \approx 1 \beta, 2 \beta=3.5,5 \alpha, 6 \alpha=6 \alpha, 7 \beta=2.1,15,16(17)=7.1$.

2: $1 \alpha, 1 \beta=12.2,1 \beta, 2 \alpha \approx 1 \beta, 2 \beta=3.0,5 \alpha, 6 \alpha=6 \alpha, 7 \beta=1.8,15,16(17)=7.0$; fatty esters: $\mathrm{Me} \mathrm{CH}_{2}=6.9$.

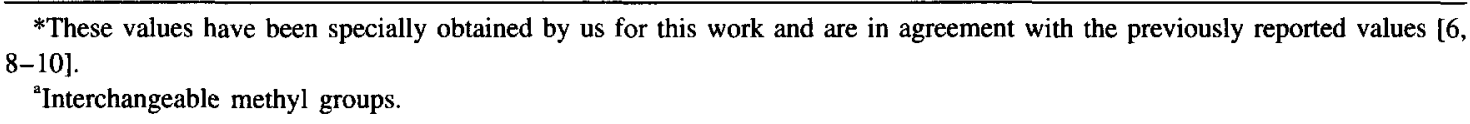

The biautographic agar overlay assay with Staphylococcus aureus $[11,12]$, was used to detect and activityguide the fractionation of antimicrobial compounds, and has revealed activity for all the royleanones isolated, but not for the grandidones. The activity showed in bioautography for the royleanones was confirmed by the determination of the minimum inhibitory concentration (MIC) against $S$. aureus. Compound 1 , with a MIC value of $31.2 \mu \mathrm{g} \mathrm{ml}^{-1}$ and horminone (MIC value previously described) [1] showed higher antibacterial activity than royleanone, 6,7-dehydroroyleanone, and $6 \beta$-hydroxyroyleanone (MIC values $\geqslant 125 \mu \mathrm{g} \mathrm{ml}^{-1}$ ). The MIC determination against the other standard bacterial strains and a yeast (see Experimental) showed that all these assayed royleanones present MIC values of $15.6 \mu \mathrm{g} \mathrm{ml}^{-1}$ against Vibrio cholerae and less activity against the rest of the strains (MIC $\geqslant 125 \mu \mathrm{g}$ $\mathrm{ml}^{-1}$ ) (see Experimental). The activities of $\mathbf{1}$ and horminone against $S$. aureus and the activities against $V$. cholerae were found to be bactericidal, considering that the MIC and the MBC (minimum bactericidal concentration) values are the same.

\section{EXPERIMENTAL}

General. Seeds of $P$. grandidentatus Gürke were provided by the National Botanic Garden, Kirstebosh, Claremont, South Africa. The plants were cultivated in the Faculty of Pharmacy HORTUM, Lisbon University, through vegetative propagation of the first specimen obtained from seed. The material was collected in July-October 1994, and voucher specimens are deposited in the Herbarium of the Department of the Organic Chemistry, Faculty of Pharmacy, University of Lisbon, Portugal.

Extraction and isolation of the diterpenoids. Dried and powdered $P$. grandidentatus (whole plant, $2.56 \mathrm{~kg}$ ) were extracted with $\mathrm{Me}_{2} \mathrm{CO}(5 \times 6 \mathrm{l})$ at room temp. for 5 days. The solvent was evapd under red. pres. and low temp. $\left(40^{\circ}\right)$ yielding a residue $(65.5 \mathrm{~g})$, which was subjected to $\mathrm{CC}$ (silica gel Merck $\mathrm{N}^{\circ} .9385,500 \mathrm{~g}$ ).
From the frs eluted with hexane-EtOAc (4:1) (12 g), the following compounds were obtained in order of increasing chromatographic polarity: royleanone (10 $\mathrm{mg})[5,6], 6,7$-dehydroroyleanone $(11 \mathrm{mg})[5,6]$, horminone (18 $\mathrm{mg}$ ), compound 2 (72 $\mathrm{mg}$ ) [5, 7], $6 \beta$-hydroxyroyleanone $(6 \mathrm{mg})[6,8], 7 \alpha$-acetoxy- $6 \beta$ hydroxyroyleanone $(1,210 \mathrm{mg})[6,8-10]$, grandidone D (4 mg) [4] grandidone C (26 mg) [4] and 7-epigrandidone D (26 mg) [4].

The previously known diterpenoids were identified by their ${ }^{\mathrm{t}} \mathrm{H}$ NMR and MS and, in some cases, by comparison (TLC) with authentic samples.

7-Fatty acid esters of $6 \beta, 7 \alpha$-dihydroxyroyleanone (2). Yellowish thick oil; $[\alpha]_{\mathrm{D}}^{21}+11.7^{\circ},[\alpha]_{578}+8.0^{\circ}$, $[\alpha]_{546}-17.1^{\circ},[\alpha]_{436}-36.6^{\circ},[\alpha]_{365}-63.8^{\circ}\left(\mathrm{CHCl}_{3}\right.$; $c 0.298)$. UV $\lambda_{\max }^{\mathrm{MeOH}} \mathrm{nm}(\log \varepsilon): 273$ (4.18), 409 (2.96), $\lambda_{\max }^{\mathrm{MeOH}+\mathrm{NaOMe}} \mathrm{nm}: 223$ (4.47), 274 (4.02), 519 (3.29), for a mean $M_{r}$ 592. IR $\nu_{\max }^{\mathrm{NaCl}} \mathrm{cm}^{-1}: 3500,3380(\mathrm{OH})$, 1730 (ester), 1660, 1645, 1615 (quinone), 2930, 2850, $1460,1380,1250,1160,1150,1100,1050,960,900$, 760. 'H NMR: Table 1.

Hydrolysis of 2 and identification of fatty acid methyl esters. To a soln of $2(20 \mathrm{mg})$ in $\mathrm{EtOH}(5 \mathrm{ml})$ was added a soln of $\mathrm{KOH}$ in EtOH $(10 \%$, w/v. $5 \mathrm{ml})$ and the reaction mixt. was left at room temp. for $24 \mathrm{hr}$. The reaction mixt. was then diluted with $\mathrm{H}_{2} \mathrm{O}(50 \mathrm{ml})$, acidified ( $\mathrm{pH} \approx 3$ ) with aq. $1.5 \mathrm{M} \mathrm{H}_{2} \mathrm{SO}_{4}$ and extracted with $\mathrm{CHCl}_{3}(4 \times 20 \mathrm{ml})$. The organic extract was dissolved in $\mathrm{Et}_{2} \mathrm{O}(5 \mathrm{ml})$ and treated with an excess of an ethereal soln of $\mathrm{CH}_{2} \mathrm{~N}_{2}$ for $2 \mathrm{hr}$ at room temp. The solvent was evapd and the crude residue subjected to GC-MS analysis under standard conditions, by using a Hewlett Packard 5890 gas chromatograph coupled to a HP 5971A mass detector. Myristic (2.6\%), n-pentadecanoic $(2.9 \%)$, palmitic $(71.7 \%), n$-heptadecanoic $(3.9 \%)$, stearic $(12.8 \%)$ and oleic $(6.1 \%)$ acids methyl esters were identified.

Microorganisms. Gram negative bacteria: Escherichia coli ATCC 25922, Shigella dysenteriae ATCC 13313, Salmonella typhimurium ATCC 43971, Pseudomonas aeruginosa ATCC 27853, Vibrio cholerae ATCC 11623; Gram positive bacteria: Staphylo- 
coccus aureus ATCC $2592^{-1} 3$, Streptococcus faecalis ATCC 10541; yeast: Candida albicans CIP 3153 A.

Bioautography. TLC plates with $0.15 \mathrm{mg}$ of each sample (silica gel, hexane-EtOAc) were covered with a suspension of the indicator strain $S$. aureus with a final concentration of $10^{6} \mathrm{cfu} \mathrm{ml} \mathrm{m}^{-1}$ and incubated at $37^{\circ}$ for $24 \mathrm{hr}[11,12]$.

Minimum inhibitory concentration (MIC). The MIC value for bacteria and yeast was determined using the three-fold serial broth microdilution assay [13] over the concentration range $500 \mu \mathrm{g} \mathrm{ml}^{-1}$ to $7.8 \mu \mathrm{g} \mathrm{ml}^{-1}$. The test compounds were added to sterile Mueller-Hinton broth medium for bacteria and YMA broth Medium for the yeast as a soln in $\mathrm{MeOH}-\mathrm{H}_{2} \mathrm{O}$ and inoculated with a microorganism concentration of $\mathrm{ca} 10^{5} \mathrm{cfu} \mathrm{ml}^{-1}$. Solvent blanks were included. The MIC value was taken as the lowest concentration of compound which inhibited the growth of the test organisms after $24 \mathrm{hr}$ incubation at $37^{\circ}$.

Minimum bactericidal concentration $(M B C)$. The bactericidal effects of the tested compounds were examined after the determination of MIC. A replica plating from each clear tube was done into a Mueller Hinton agar. After $24 \mathrm{hr}$ at $37^{\circ}$ the $\mathrm{MBC}$ was determined as the lowest concentration of the test sample in which no recovery of microorganisms was obtained [13].

Acknowledgements - The authors thank Dr J. Sanz and Ms M. Jiménez, CSIC Madrid, for GC-MS analysis. This work was supported by grants from JNICT (PBIC/ C/BIO/1100/92, Portugal) and DGICYT (PB93-0154, Spain).

\section{REFERENCES}

1. Batista, O., Duarte, A., Nascimento, J., Simões, M. F., de la Torre, M. C. and Rodríguez, B. (1994) $J$. Nat. Prod. 57, 858.

2. Batista, O., Simões, M. F., Duarte, A., Valdeira, M. L., de la Torre, M. C. and Rodríguez, B. (1995) Phytochemistry 38, 167.

3. Batista, O., Simões, M. F., Nascimento, J., Ribeiro, S., Duarte, A., Rodríguez, B. and de la Torre, M. C. (1996) Phytochemistry 41, 571.

4. Uchida, M., Miyase, T., Yoshizaki, F., Bieri, J. H., Rüedi, P. and Eugster, C. H. (1981) Helv. Chim. Acta 64, 2227.

5. Edwards, O. E., Feniak, G. and Los, M. (1962) Can. J. Chem. 40, 1540.

6. Hensch, M. M., Rüedi, P. and Eugster, C. H. (1975) Helv. Chim Acta 58, 1921.

7. Janot, M. M. and Potier, P. (1964) Ann. Pharm. Franç. 22, 387.

8. Yoshizaki, F., Rüedi, P. and Eugster, C. H. (1979) Helv. Chim. Acta 62, 2754.

9. Alder, A. C., Rüedi, P. and Eugster, C. H. (1984) Helv. Chim. Acta 67, 1523.

10. Matloubi-Moghadam F., Rüedi, P. and Eugster, C. H. (1987) Helv. Chim. Acta 70, 975.

11. Slusarenko, A. J., Longland A. C. and Whitehead I. M. (1989) Botan. Helv. 99/2, 203.

12. Rahalison, L., Hamburger, M., Hostettmann, K., Monod, M. and Frenk, E. (1991) Phytochem. Analysis 2, 199.

13. BSAC Working Party (1991) J. Antimicrob. Chemother. 27, 22. 